Research Paper

\title{
Hl9 gene polymorphisms and neuroblastoma susceptibility in Chinese children: a six-center case-control study
}

\author{
Yong Li1, Zhen-Jian Zhuo', Haiyan Zhou'3, Jiabin Liu², Jiao Zhang4, Jiwen Cheng5, Haixia Zhou', Suhong \\ $\mathrm{Li}^{7}$, Ming $\mathrm{Li}^{1}$, Jun $\mathrm{He}^{1}$, Zhenghui Xiao ${ }^{8}$, Jing $\mathrm{He}^{2 \bowtie}$, Yaling Xiao ${ }^{\circledR}$ \\ 1. Department of Pediatric Surgery, Hunan Children's Hospital, Changsha 410004, Hunan, China. \\ 2. Department of Pediatric Surgery, Guangzhou Institute of Pediatrics, Guangdong Provincial Key Laboratory of Research in Structural Birth Defect Disease, \\ Guangzhou Women and Children's Medical Center, Guangzhou Medical University, Guangzhou 510623, Guangdong, China. \\ 3. Department of Pathology, Xiang-ya School of Medicine, Central South University, Changsha 410013, Hunan, China. \\ 4. Department of Pediatric Surgery, the First Affiliated Hospital of Zhengzhou University, Zhengzhou 450052, Henan, China. \\ 5. Department of Pediatric Surgery, the Second Affiliated Hospital of Xi'an Jiaotong University, Xi' an 710004, Shaanxi, China. \\ 6. Department of Hematology, The Second Affiliated Hospital and Yuying Children's Hospital of Wenzhou Medical University, Wenzhou 325027, Zhejiang, \\ China. \\ 7. Department of Pathology, Children Hospital and Women Health Center of Shanxi, Taiyuan 030013, Shannxi, China. \\ 8. Emergency center of Hunan Children's Hospital, Changsha 410004, Hunan, China. \\ $\square$ Corresponding authors: Yaling Xiao, Department of Pediatric Surgery, Hunan Children's Hospital, 86 Ziyuan Road, Changsha 410004, Hunan, China, Email: \\ etyypwk@sina.com; or Jing He, Department of Pediatric Surgery, Guangzhou Institute of Pediatrics, Guangdong Provincial Key Laboratory of Research in \\ Structural Birth Defect Disease, Guangzhou Women and Children's Medical Center, Guangzhou Medical University, 9 Jinsui Road, Guangzhou 510623, \\ Guangdong, China, Email: hejing198374@gmail.com.
}

(1) The author(s). This is an open access article distributed under the terms of the Creative Commons Attribution License (https://creativecommons.org/licenses/by/4.0/). See http://ivyspring.com/terms for full terms and conditions.

Received: 2019.06.13; Accepted: 2019.09.21; Published: 2019.10.18

\begin{abstract}
Neuroblastoma is the most common seen solid tumor in children less than one year old. Given that polymorphisms in the IncRNA HI 9 gene are observed in several types of human malignancies, there likely to be similar events that contribute to the pathogenesis of neuroblastoma. We hypothesize that single nucleotide polymorphisms (SNPs) in the $\mathrm{Hl} 9$ gene might predispose to neuroblastoma. Here, we genotyped three SNPs (rs2839698 G>A, rs3024270 C>G, rs217727 G>A) from H19 gene in a Chinese population (700 subjects with neuroblastoma and 1516 control subjects) enrolled from six hospitals and examined the effect of individual and combined SNPs on the risk of neuroblastoma. Odds ratios (ORs) and $95 \%$ confidence intervals $(\mathrm{Cls})$ calculated from logistic regression were adopted to assess such association, adjusted for age and gender. Among them, 700 controls and 1514 cases were successfully genotyped. None of these three SNPs were found to be relevant to the risk of neuroblastoma, either in overall analysis or stratification analysis. Findings from this study excluded the participation of IncRNA $\mathrm{HI} 9$ gene SNPs in the risk of neuroblastoma. More independent case-control studies are encouraged to better elucidate this relationship.
\end{abstract}

Key words: lncRNA; H19; polymorphism; neuroblastoma; susceptibility

\section{Introduction}

Neuroblastoma is a childhood tumor that mainly derives from neural crest progenitor cells [1, 2]. Despite its occupation rate of $8-10 \%$ of all pediatric cancer diagnoses, neuroblastoma disproportionately results in $12-15 \%$ of all childhood cancer related mortality [3-5]. It is characterized by widely clinical heterogeneity, spanning from spontaneous regression to therapy-refractory progression [6, 7]. Another reflection of such heterogeneity was the contrasting survival rate of different subgroup patients [8]. In patients with the low- and intermediate-risk neuroblastoma, the long-term survival rate is greater than $90 \%$. However, in patients with the high-risk neuroblastoma, less than $40 \%$ could finally survived 
[9-12].

In the past decades, considerable progress has been made in understanding the genetic underpinnings of neuroblastoma. Exposed environmental factors of children and pregnant women were reported to predispose to neuroblastoma, but not finally defined [13, 14]. Mutations in $A L K$ and $P H O X 2 B$ were considered as two major causes of familial neuroblastoma. Other genetic variants in genes including LMO1 [15], BARD1 [16], TP53 [17], DUSP12 [18], LIN28B [19], HACE1 [19], NEFL [20] and CDKN1B [21] have more recently been associated with neuroblastoma predisposition. Moreover, fine mapping study also identified neuroblastoma-associated functional risk SNPs in BARD1 [22]. Taken together, however, all the current identified variants still could not fully elucidate the etiology of neuroblastoma. We still have a long way to fully reveal the genetic landscape of neuroblastoma. Identification of other somatic mutations and polymorphisms will further clarify the mechanisms of neuroblastoma.

Long non-coding RNAs (lncRNAs), longer than 200 nucleotides, are a class of non-protein-coding transcripts. LncRNAs regulate multiple physiological and pathological processes by different mechanisms, including transcriptional regulation, genome rearrangement, imprinting, epigenetic regulation, and chromatin modification. Accumulating evidence point to the critical role of lncRNAs in human disorders especially in cancers. H19 gene was the first lncRNA discovered in the human genome [23, 24]. H19 gene is exclusively expressed from maternal chromosome, treated as a paternally imprinted oncofetal gene [25]. H19 gene is incompetent to encode for a protein, but instead encodes for a polyadenylated, spliced, and capped ncRNA spans $2.7 \mathrm{~kb}$ long [23]. H19 gene has been reported as a cancer-associated lncRNA that functions as both oncogene and suppressor gene. Mounting proof have been achieved in the modulation ability of single nucleotide polymorphisms (SNPs) within lncRNAs in causing tumor susceptibility. Thus far, most studies have addressed the identification of $H 19$ gene SNPs in bladder cancer [26], hepatocellular cancer [27], and lung cancer [28], whereas few studies focused on the role of $H 19$ gene SNPs in neuroblastoma risk. Here we conducted a six-center hospital-based case-control study aiming to investigate the association between SNPs within the H19 gene and neuroblastoma risk.

\section{Materials and Methods}

\section{Study subjects}

The enrollment criteria of subjects were described in previous studies [29-32]. Prior to analysis, the study protocols were approved by the Institutional Review Board of each hospital. The current case-control study was carried out in 6 hospitals in 6 provinces of China. A total of 700 cases were pathology-confirmed with neuroblastoma, and classified clinical stages according to the INSS [33], and 1516 controls with no prior history of neuroblastoma were randomly enrolled in the same area as cases. To be specific, 275 cases and 531 controls were from Guangzhou Women and Children's Medical Center [34], 162 cases and 270 controls were from Hunan Children's Hospital [35], 118 cases and 281 controls were from The First Affiliated Hospital of Zhengzhou University [36, 37], 76 cases and 186 controls were from The Second Affiliated Hospital of Xi'an Jiaotong University [38], 36 cases and 72 controls were from The Second Affiliated Hospital and Yuying Children's Hospital of Wenzhou Medical University [39, 40], and 33 cases and 176 controls were from Children's Hospital of Shanxi. All guardians of participants provided written informed consent.

\section{Polymorphism selection and genotyping}

We screened NCBI dbSNP database (http://www.ncbi.nlm.nih.gov/projects/SNP) and SNPinfo (http://snpinfo.niehs.nih.gov/snpfunc.htm) to select potential functional neuroblastoma-risk SNPs. Three SNPs (rs2839698 G>A, rs3024270 C>G, rs217727 G>A) in $H 19$ gene that met the previously described criteria were selected for inclusion [41]. The rs2839698 G>A and rs3024270 C>G are located in the transcription factor binding sites. As shown in Supplemental Figure s1, there was no significant linkage disequilibrium $\left(\mathrm{R}^{2}<0.8\right)$ among these three SNPs $\left(R^{2}=0.408\right.$ between $r s 217727$ and rs3024270; $\mathrm{R}^{2}=0.213$ between $\mathrm{rs} 217727$ and $\mathrm{rs} 2839698 ; \mathrm{R}^{2}=0.508$ between rs3024270 and rs2839698). Genomic DNA was isolated from venous blood using a TIANamp Blood DNA Kit (TianGen Biotech Co. Ltd., Beijing, China). Genotype analysis of all three H19 gene SNPs was undertaken using TaqMan SNP Genotyping Assay from Applied Biosystem using 7900 Real-Time PCR system [42-45]. Negative controls (with water) and duplicate test samples ( $10 \%$ of all the samples) were included in each 384-well plate. 100\% concordant of genotypes in replicates were achieved.

\section{Statistical analysis}

Tests for Hardy-Weinberg equilibrium (HWE) were conducted for each SNP separately among control subjects with the use of $\chi^{2}$ test. Differences in demographic variables between case subjects and control subjects were analyzed using the two-sided $\chi^{2}$ test. Neuroblastoma risk was determined as odds 
ratios (ORs) and 95\% confidence intervals (CIs), based on unconditional logistic regression adjusted for age and gender. A $P$-value of $<0.05$ was used for statistical significance. The SAS release 9.1 (SAS Institute, Cary, NC) was used for statistical analyses.

\section{Results}

\section{Association between $\mathrm{H} 19$ polymorphisms and neuroblastoma susceptibility}

We enrolled 700 cases with neuroblastoma and 1516 controls without neuroblastoma from 6 hospitals in 6 provinces of China (Supplemental Table 1), and no significant differences were observed between cases and controls for age $(P=0.525)$ and gender $(P=0.796)$. We successfully genotyped 700 controls and 1514 cases. The genotype distributions of H19 gene polymorphisms (rs2839698 G>A, rs3024270 $\mathrm{C}>\mathrm{G}$, rs217727 G>A) and their associations with neuroblastoma susceptibility were summarized in Table 1. In the controls, the genotype frequencies of all the three SNPs conformed to Hardy-Weinberg equilibrium (HWE $=0.406$ for $r$ s2839698 $\mathrm{G}>\mathrm{A}$, $\mathrm{HWE}=0.162$ for $\mathrm{rs} 3024270 \mathrm{C}>\mathrm{G}, \mathrm{HWE}=0.744$ for rs217727 G>A). Our results indicated that none of the SNPs included were significantly associated with neuroblastoma susceptibility. We also failed to find significantly statistical correlation between the combined effect of risk genotypes and the susceptibility of neuroblastoma.

\section{Stratification analysis}

We further carried out stratified analysis to analyze the association between H19 gene polymorphisms and neuroblastoma susceptibility under different subtypes including age, gender, tumor sites, and INSS stages (Table 2). However, we still could not obtain significant association between all the three polymorphisms, neither in single nor combined analysis, and neuroblastoma susceptibility under all the strata.

\section{Haplotype analysis}

As shown in Table 3, we failed to find any haplotype that was significantly associated with neuroblastoma risk.

\section{Discussion}

In this study, we investigated whether lncRNA $H 19$ gene polymorphisms were involved in the risk of neuroblastoma in Chinese population using individuals from six centers. Our results showed that none of the H19 gene polymorphisms contributed to the risk of neuroblastoma. Conclusions obtained here represent an important extension of our understanding of how $\mathrm{H} 19$ gene polymorphism is not relevant to neuroblastoma risk.

Table 1. Associations between $\mathrm{H} 19$ polymorphisms and neuroblastoma susceptibility

\begin{tabular}{|c|c|c|c|c|c|c|c|}
\hline Genotype & $\begin{array}{l}\text { Cases } \\
(\mathrm{N}=700)\end{array}$ & $\begin{array}{l}\text { Controls } \\
(\mathrm{N}=1514)\end{array}$ & $P a$ & $\begin{array}{l}\text { Crude OR } \\
(95 \% \mathrm{CI})\end{array}$ & $P$ & $\begin{array}{l}\text { Adjusted OR } \\
(95 \% \mathrm{CI})^{\mathrm{b}}\end{array}$ & $P_{\mathrm{b}}$ \\
\hline \multicolumn{8}{|c|}{ rs2839698 G>A (HWE=0.406) } \\
\hline GG & $331(47.29)$ & $704(46.50)$ & & 1.00 & & 1.00 & \\
\hline AG & $300(42.86)$ & $667(44.06)$ & & $0.96(0.79-1.16)$ & 0.646 & $0.96(0.79-1.16)$ & 0.658 \\
\hline AA & $69(9.86)$ & $143(9.45)$ & & $1.03(0.75-1.41)$ & 0.871 & $1.04(0.76-1.43)$ & 0.805 \\
\hline Additive & & & 0.858 & $0.99(0.86-1.14)$ & 0.900 & $1.00(0.87-1.14)$ & 0.956 \\
\hline Dominant & $369(52.71)$ & $810(53.50)$ & 0.730 & $0.97(0.81-1.16)$ & 0.730 & $0.97(0.81-1.16)$ & 0.762 \\
\hline Recessive & $631(90.14)$ & $1371(90.55)$ & 0.759 & $1.05(0.78-1.42)$ & 0.758 & $1.06(0.79-1.44)$ & 0.696 \\
\hline \multicolumn{8}{|c|}{ rs3024270 C>G (HWE=0.162) } \\
\hline $\mathrm{CC}$ & $184(26.29)$ & $415(27.41)$ & & 1.00 & & 1.00 & \\
\hline CG & $362(51.71)$ & $781(51.59)$ & & $1.05(0.84-1.29)$ & 0.684 & $1.05(0.85-1.30)$ & 0.679 \\
\hline GG & $154(22.00)$ & $318(21.00)$ & & $1.09(0.84-1.42)$ & 0.505 & $1.09(0.84-1.42)$ & 0.505 \\
\hline Additive & & & 0.799 & $1.05(0.92-1.19)$ & 0.503 & $1.05(0.92-1.19)$ & 0.503 \\
\hline Dominant & $516(73.71)$ & 1099 (72.59) & 0.580 & $1.06(0.87-1.30)$ & 0.580 & $1.06(0.87-1.30)$ & 0.576 \\
\hline Recessive & $546(78.00)$ & $1196(79.00)$ & 0.595 & $1.06(0.85-1.32)$ & 0.595 & $1.06(0.85-1.32)$ & 0.598 \\
\hline \multicolumn{8}{|c|}{ rs217727 G>A (HWE=0.744) } \\
\hline GG & $331(47.29)$ & $679(44.85)$ & & 1.00 & & 1.00 & \\
\hline AG & $289(41.29)$ & $674(44.52)$ & & $0.88(0.73-1.06)$ & 0.187 & $0.88(0.72-1.06)$ & 0.172 \\
\hline $\mathrm{AA}$ & $80(11.43)$ & $161(10.63)$ & & $1.02(0.76-1.37)$ & 0.900 & $1.02(0.75-1.37)$ & 0.922 \\
\hline Additive & & & 0.359 & $0.96(0.84-1.10)$ & 0.591 & $0.96(0.84-1.10)$ & 0.561 \\
\hline Dominant & $369(52.71)$ & $835(55.15)$ & 0.284 & $0.91(0.76-1.09)$ & 0.284 & $0.90(0.75-1.08)$ & 0.263 \\
\hline Recessive & $620(88.57)$ & $1353(89.37)$ & 0.577 & $1.08(0.82-1.44)$ & 0.577 & $1.08(0.81-1.44)$ & 0.586 \\
\hline \multicolumn{8}{|c|}{ Combined effect of risk genotypes c } \\
\hline 0 & $112(16.00)$ & $258(17.04)$ & & 1.00 & & 1.00 & \\
\hline 1 & $511(73.00)$ & $1109(73.25)$ & & $1.06(0.83-1.36)$ & 0.634 & $1.06(0.83-1.36)$ & 0.643 \\
\hline 2 & $77(11.00)$ & $147(9.71)$ & & $1.21(0.85-1.72)$ & 0.298 & $1.22(0.86-1.74)$ & 0.272 \\
\hline $1-2$ & $588(84.00)$ & $1256(82.96)$ & 0.542 & $1.08(0.85-1.37)$ & 0.542 & $1.08(0.85-1.38)$ & 0.542 \\
\hline
\end{tabular}


Table 2. Stratification analysis for association between $\mathrm{H} / 9$ genotypes and neuroblastoma susceptibility

\begin{tabular}{|c|c|c|c|c|c|c|c|c|c|c|c|c|c|c|c|c|}
\hline \multirow[t]{2}{*}{ Variables } & \multicolumn{2}{|c|}{$\begin{array}{l}\text { rs2839698 } \\
\text { (case/control) }\end{array}$} & \multirow[t]{2}{*}{$\begin{array}{l}\text { AOR }(95 \% \\
\text { CI })^{\mathrm{a}}\end{array}$} & \multirow[t]{2}{*}{$P a$} & \multicolumn{2}{|c|}{$\begin{array}{l}\text { rs3024270 } \\
\text { (case/control) }\end{array}$} & \multirow[t]{2}{*}{$\begin{array}{l}\mathrm{AOR}(95 \% \\
\mathrm{CI})^{\mathrm{a}}\end{array}$} & \multirow[t]{2}{*}{$P a$} & \multicolumn{2}{|c|}{$\begin{array}{l}\text { rs217727 } \\
\text { (case/control) }\end{array}$} & \multirow[t]{2}{*}{$\begin{array}{l}\text { AOR }(95 \% \\
\mathrm{CI})^{\mathrm{a}}\end{array}$} & \multirow[t]{2}{*}{$P a$} & \multicolumn{2}{|c|}{$\begin{array}{l}\text { Risk genotypes } \\
\text { (case/control) }\end{array}$} & \multirow[t]{2}{*}{$\begin{array}{l}\mathrm{AOR}(95 \% \\
\mathrm{CI})^{\mathrm{a}}\end{array}$} & \multirow[t]{2}{*}{$P a$} \\
\hline & GG/AG & AA & & & $\mathrm{CC}$ & CG/GG & & & GG/AG & $\mathrm{AA}$ & & & 0 & $1-2$ & & \\
\hline \multicolumn{17}{|l|}{ Age, month } \\
\hline$\leq 18$ & $243 / 554$ & $31 / 61$ & $\begin{array}{l}1.14 \\
(0.72-1.80)\end{array}$ & 0.589 & $69 / 182$ & $205 / 433$ & $\begin{array}{l}1.25 \\
(0.90-1.72)\end{array}$ & 0.184 & $248 / 538$ & $26 / 77$ & $\begin{array}{l}0.73 \\
(0.46-1.17)\end{array}$ & 0.189 & $44 / 107$ & $230 / 508$ & $\begin{array}{l}1.09 \\
(0.74-1.60)\end{array}$ & 0.662 \\
\hline$>18$ & $388 / 817$ & $38 / 82$ & $\begin{array}{l}0.97 \\
(0.65-1.45)\end{array}$ & 0.880 & $115 / 233$ & $311 / 666$ & $\begin{array}{l}0.95 \\
(0.73-1.23)\end{array}$ & 0.679 & $372 / 815$ & $54 / 84$ & $\begin{array}{l}1.40 \\
(0.98-2.02)\end{array}$ & 0.068 & $68 / 151$ & $358 / 748$ & $\begin{array}{l}1.06 \\
(0.78-1.45)\end{array}$ & 0.703 \\
\hline \multicolumn{17}{|l|}{ Gender } \\
\hline Female & $273 / 600$ & $34 / 55$ & $\begin{array}{l}1.37 \\
(0.87-2.15)\end{array}$ & 0.177 & $76 / 188$ & $231 / 467$ & $\begin{array}{l}1.22 \\
(0.90-1.67)\end{array}$ & 0.206 & $274 / 581$ & $33 / 74$ & $\begin{array}{l}0.93 \\
(0.60-1.44)\end{array}$ & 0.744 & $49 / 117$ & $258 / 538$ & $\begin{array}{l}1.13 \\
(0.78-1.63)\end{array}$ & 0.520 \\
\hline Male & $358 / 771$ & $35 / 88$ & $\begin{array}{l}0.87 \\
(0.57-1.31)\end{array}$ & 0.490 & $108 / 227$ & $285 / 632$ & $\begin{array}{l}0.95 \\
(0.73-1.24)\end{array}$ & 0.700 & $346 / 772$ & $47 / 87$ & $\begin{array}{l}1.21 \\
(0.83-1.76)\end{array}$ & 0.325 & $63 / 141$ & $330 / 718$ & $\begin{array}{l}1.03 \\
(0.75-1.43)\end{array}$ & 0.848 \\
\hline \multicolumn{17}{|l|}{ Sites of origin } \\
\hline Adrenal gland & $196 / 1371$ & $19 / 143$ & $\begin{array}{l}0.94 \\
(0.57-1.55)\end{array}$ & 0.808 & $58 / 415$ & $157 / 1099$ & $\begin{array}{l}1.02 \\
(0.74-1.40)\end{array}$ & 0.927 & $185 / 1353$ & $30 / 161$ & $\begin{array}{l}1.38 \\
(0.90-2.10)\end{array}$ & 0.138 & $34 / 258$ & $181 / 1256$ & $\begin{array}{l}1.09 \\
(0.74-1.61)\end{array}$ & 0.673 \\
\hline Retroperitoneal & $219 / 1371$ & $21 / 143$ & $\begin{array}{l}0.92 \\
(0.57-1.49)\end{array}$ & 0.746 & $61 / 415$ & $179 / 1099$ & $\begin{array}{l}1.10 \\
(0.81-1.51)\end{array}$ & 0.544 & $217 / 1353$ & $23 / 161$ & $\begin{array}{l}0.90 \\
(0.57-1.42)\end{array}$ & 0.641 & $38 / 258$ & $202 / 1256$ & $\begin{array}{l}1.09 \\
(0.75-1.58)\end{array}$ & 0.663 \\
\hline Mediastinum & $157 / 1371$ & $20 / 143$ & $\begin{array}{l}1.24 \\
(0.75-2.04)\end{array}$ & 0.398 & $45 / 415$ & $132 / 1099$ & $\begin{array}{l}1.12 \\
(0.78-1.60)\end{array}$ & 0.530 & $157 / 1353$ & $20 / 161$ & $\begin{array}{l}1.06 \\
(0.65-1.74)\end{array}$ & 0.814 & $26 / 258$ & $151 / 1256$ & $\begin{array}{l}1.21 \\
(0.78-1.87)\end{array}$ & 0.394 \\
\hline Others & $52 / 1371$ & $8 / 143$ & $\begin{array}{l}1.44 \\
(0.67-3.10)\end{array}$ & 0.347 & $15 / 415$ & $45 / 1099$ & $\begin{array}{l}1.14 \\
(0.63-2.07)\end{array}$ & 0.671 & $55 / 1353$ & $5 / 161$ & $\begin{array}{l}0.76 \\
(0.30-1.92)\end{array}$ & 0.559 & $11 / 258$ & $49 / 1256$ & $\begin{array}{l}0.92 \\
(0.47-1.79)\end{array}$ & 0.796 \\
\hline \multicolumn{17}{|l|}{ Clinical stages } \\
\hline $\mathrm{I}+\mathrm{II}+4 \mathrm{~s}$ & $311 / 1371$ & $34 / 143$ & $\begin{array}{l}1.05 \\
(0.71-1.55)\end{array}$ & 0.823 & $97 / 415$ & $248 / 1099$ & $\begin{array}{l}0.97 \\
(0.75-1.26)\end{array}$ & 0.806 & $304 / 1353$ & $41 / 161$ & $\begin{array}{l}1.13 \\
(0.79-1.63)\end{array}$ & 0.504 & $58 / 258$ & $287 / 1256$ & $\begin{array}{l}1.02 \\
(0.75-1.39)\end{array}$ & 0.902 \\
\hline III+IV & $297 / 1371$ & $33 / 143$ & $\begin{array}{l}1.11 \\
(0.74-1.66)\end{array}$ & 0.616 & $80 / 415$ & $250 / 1099$ & $\begin{array}{l}1.18 \\
(0.90-1.56)\end{array}$ & 0.233 & $294 / 1353$ & $36 / 161$ & $\begin{array}{l}1.03 \\
(0.70-1.52)\end{array}$ & 0.883 & $50 / 258$ & $280 / 1256$ & $\begin{array}{l}1.16 \\
(0.83-1.61)\end{array}$ & 0.396 \\
\hline
\end{tabular}

AOR, adjusted odds ratio; $\mathrm{CI}$, confidence interval. a Adjusted for age and gender, omitting the corresponding stratify factor.

Table 3. The frequency of inferred haplotypes of $\mathrm{HI} 9$ based on observed genotypes and their association with neuroblastoma susceptibility

\begin{tabular}{|c|c|c|c|c|c|c|}
\hline $\begin{array}{l}\text { Haplotypes } \\
\text { a }\end{array}$ & $\begin{array}{l}\text { Cases } \\
(\mathrm{n}=1400)\end{array}$ & $\begin{array}{l}\text { Controls } \\
(n=3028)\end{array}$ & $\begin{array}{l}\text { Crude OR } \\
(95 \% \text { CI })\end{array}$ & $P$ & $\begin{array}{l}\text { Adjusted OR } \\
\mathrm{b} \\
(95 \% \mathrm{CI})\end{array}$ & $P \mathrm{~b}$ \\
\hline GCG & $\begin{array}{l}496 \\
(35.43)\end{array}$ & $\begin{array}{l}1098 \\
(36.26)\end{array}$ & 1.00 & & 1.00 & \\
\hline GCA & $\begin{array}{l}226 \\
(16.14)\end{array}$ & $501(16.55)$ & $\begin{array}{l}1.00 \\
(0.83-1.21)\end{array}$ & 0.988 & $\begin{array}{l}1.00 \\
(0.82-1.20)\end{array}$ & 0.966 \\
\hline GGG & $\begin{array}{l}156 \\
(11.14)\end{array}$ & 303 (10.01) & $\begin{array}{l}1.14 \\
(0.91-1.42)\end{array}$ & 0.245 & $\begin{array}{l}1.14 \\
(0.91-1.42)\end{array}$ & 0.259 \\
\hline GGA & $84(6.00)$ & $173(5.71)$ & $\begin{array}{l}1.08 \\
(0.81-1.42)\end{array}$ & 0.615 & $\begin{array}{l}1.07 \\
(0.80-1.41)\end{array}$ & 0.659 \\
\hline ACG & $2(0.14)$ & $5(0.17)$ & $\begin{array}{l}0.89 \\
(0.17-4.58)\end{array}$ & 0.885 & $\begin{array}{l}0.95 \\
(0.18-4.90)\end{array}$ & 0.947 \\
\hline ACA & $6(0.43)$ & $7(0.23)$ & $\begin{array}{l}1.90 \\
(0.63-5.68)\end{array}$ & 0.252 & $\begin{array}{l}1.96 \\
(0.65-5.87)\end{array}$ & 0.230 \\
\hline AGG & $\begin{array}{l}297 \\
(21.21)\end{array}$ & $626(20.67)$ & $\begin{array}{l}1.05 \\
(0.88-1.25)\end{array}$ & 0.581 & $\begin{array}{l}1.05 \\
(0.89-1.25)\end{array}$ & 0.558 \\
\hline AGA & $133(9.50)$ & $315(10.40)$ & $\begin{array}{l}0.94 \\
(0.74-1.18)\end{array}$ & 0.563 & $\begin{array}{l}0.94 \\
(0.74-1.18)\end{array}$ & 0.567 \\
\hline
\end{tabular}

OR, odds ratio; CI, confidence interval. a The haplotypes order were rs2839698, rs3024270, and rs217727. b Obtained in logistic regression models with adjustment for age and gender.

The $H 19$ gene is located in human chromosome 11p15.5 locus. The expression level of $H 19$ gene peaks at the early stages of embryogenesis, then falls postnatally [46, 47], and is reactivated during tumorigenesis in some cancer types [48, 49]. The critical role of $\mathrm{H} 19$ gene in carcinogenesis was intensively reported. Wada et al. [50] detected a maintenance of normal imprinting of the $\mathrm{H} 19$ gene in neuroblastoma. Liang et al. [51] found that the lncRNA H19 gene promotes epithelial to mesenchymal transition of colorectal cancer by functioning as part of miRNA sponges.
Barsyte-Lovejoy et al. [52] showed that down regulation of $\mathrm{H} 19$ gene attenuated the clonogenicity of lung cancer and breast cancer. They also provided a strong association between $\mathrm{H} 19$ gene expression and primary lung and breast carcinomas. By now, some SNPs located on $H 19$ gene were identified to be associated with cancer susceptibility. In a study conducted by Guo et al. [53], it was found that rs217727 AA genotype of $H 19$ gene contributes to the susceptibility of oral squamous cell carcinoma in Chinese population. $\mathrm{Li}$ et al. [28] conducted a case-control study in lung cancer using 555 cases and 618 healthy controls. Their results gave some indication that AA genotype of rs217727 SNP in lncRNA H19 gene plays a positive role in susceptibility to lung cancer.

We have previously conducted an initial investigation of how H19 gene SNPs (rs2839698, rs3024270, and rs217727) regulate the risk of neuroblastoma in Chinese population [54]. At that time, we only genotyped 393 neuroblastoma patients and 812 control subjects from two hospitals. Our previous results failed to reveal significant associations of the three selected polymorphisms and neuroblastoma susceptibility, in separated and combined analyses. However, we detected an increased neuroblastoma risk in rs3024270 GG genotype in female Chinese children. SNPs analyzed in our previous and the current studies are all located in the H19 gene. It has been elucidated that these SNPs altered the folding architectures of H19 gene, which may result in changes of $H 19$ gene expression or functions [55]. Given that lncRNA H19 gene is 
critical in carcinogenesis, better understanding is needed of how lncRNA H19 gene SNPs might impact neuroblastoma risk. Herein, we adopted a larger sample size enrolled from six hospitals in China to get a more generalized conclusion. Again, we failed to detect the impact of $H 19$ gene SNPs on the risk of neuroblastoma. Moreover, the contributing role of rs3024270 GG in neuroblastoma risk in female Chinese children found in our previous study disappeared in the current larger study. Such conclusion inconsistency may be attributed to the relative compromised statistic power caused by the small sample size in the stratification analysis.

Strength of the current study also accompany some limitations. First, statistic power might be compromised as sample size is not large enough, although this is a multi-center study. Second, as a hospital-based case-control study, inclusion of the non-representative subjects in this study may result in inherent selection bias. Third, conclusions obtained here lack generalizability as subjects are all genetic Chinese descendants. Therefore, cautions should be taken if extrapolated the current conclusion to other populations. Fourth, the selected SNPs were based on prior knowledge of potentially functional SNPs. Other important tagging SNPs within H19 gene may be omitted. Last, environment factors and gene-environment interactions could not be assessed in the current study, with the absence of environmental data.

In conclusion, here we failed to provide the possibility of lncRNA H19 gene SNPs in predicting neuroblastoma risk. Our study serves as a basis for future replication studies in independent populations or for functional studies of lncRNA H19 gene SNPs in neuroblastoma risk.

\section{Abbreviations}

lncRNA, long non-coding RNA; SNP, single nucleotide polymorphism; HWE, Hardy-Weinberg equilibrium; OR, odds ratio; $\mathrm{CI}$, confidence interval.

\section{Supplementary Material}

Supplementary figures and tables.

http://www.jcancer.org/v10p6358s1.pdf

\section{Acknowledgments}

This work was supported by grants from Pearl River S\&T Nova Program of Guangzhou (No: 201710010086), Hunan Provincial Natural Science Foundation Project (No: 2018JJ2210), Hunan provincial key laboratory of Pediatric emergency medicine (No: 2018TP1028) and Guangdong Provincial Key Laboratory of Research in Structural Birth Defect Disease (No: 2019B030301004).

\section{Competing Interests}

The authors have declared that no competing interest exists.

\section{References}

1. Matthay KK, Maris JM, Schleiermacher G, Nakagawara A, Mackall CL, Diller L, et al. Neuroblastoma. Nat Rev Dis Primers. 2016; 2: 16078.

2. Capasso M, Diskin SJ. Genetics and genomics of neuroblastoma. Cancer Treat Res. 2010; 155: 65-84.

3. Irwin MS, Park JR. Neuroblastoma: paradigm for precision medicine. Pediatr Clin North Am. 2015; 62: 225-56.

4. Park JR, Bagatell R, Cohn SL, Pearson AD, Villablanca JG, Berthold F, et al. Revisions to the International Neuroblastoma Response Criteria: A Consensus Statement From the National Cancer Institute Clinical Trials Planning Meeting. J Clin Oncol. 2017; 35: 2580-7.

5. Esposito MR, Aveic S, Seydel A, Tonini GP. Neuroblastoma treatment in the post-genomic era. J Biomed Sci. 2017; $24: 14$.

6. Maris JM. Recent advances in neuroblastoma. N Engl J Med. 2010; 362: 2202-11.

7. Westermann F, Schwab M. Genetic parameters of neuroblastomas. Cancer Lett. 2002; 184: 127-47.

8. Durinck K, Speleman F. Epigenetic regulation of neuroblastoma development. Cell Tissue Res. 2018; 372: 309-24.

9. Cheung NK, Dyer MA. Neuroblastoma: developmental biology, cancer genomics and immunotherapy. Nat Rev Cancer. 2013; 13: 397-411.

10. Schwab M, Westermann F, Hero B, Berthold F. Neuroblastoma: biology and molecular and chromosomal pathology. Lancet Oncol. 2003; 4: 472-80.

11. Maris JM, Hogarty MD, Bagatell R, Cohn SL. Neuroblastoma. Lancet. 2007; 369: 2106-20.

12. Heinemann V, von Weikersthal LF, Decker T, Kiani A, Vehling-Kaiser U, Al-Batran SE, et al. FOLFIRI plus cetuximab versus FOLFIRI plus bevacizumab as first-line treatment for patients with metastatic colorectal cancer (FIRE-3): a randomised, open-label, phase 3 trial. Lancet Oncol. 2014; 15: $1065-75$

13. Cook MN, Olshan AF, Guess HA, Savitz DA, Poole C, Blatt J, et al. Maternal medication use and neuroblastoma in offspring. Am J Epidemiol. 2004; 159: 721-31

14. Menegaux F, Olshan AF, Neglia JP, Pollock BH, Bondy ML. Day care, childhood infections, and risk of neuroblastoma. Am J Epidemiol. 2004; 159: 843-51.

15. Oldridge DA, Wood AC, Weichert-Leahey N, Crimmins I, Sussman R, Winter $\mathrm{C}$, et al. Genetic predisposition to neuroblastoma mediated by a LMO1 super-enhancer polymorphism. Nature. 2015; 528: 418-21.

16. Latorre V, Diskin SJ, Diamond MA, Zhang H, Hakonarson H, Maris JM, et al. Replication of neuroblastoma SNP association at the BARD1 locus in African-Americans. Cancer Epidemiol Biomarkers Prev. 2012; 21: 658-63.

17. Diskin SJ, Capasso M, Diamond M, Oldridge DA, Conkrite K, Bosse KR, et al. Rare variants in TP53 and susceptibility to neuroblastoma. J Natl Cancer Inst. 2014; 106: dju047.

18. Nguyen le B, Diskin SJ, Capasso M, Wang K, Diamond MA, Glessner J, et al. Phenotype restricted genome-wide association study using a gene-centric approach identifies three low-risk neuroblastoma susceptibility Loci. PLoS Genet. 2011; 7: e1002026.

19. Diskin SJ, Capasso M, Schnepp RW, Cole KA, Attiyeh EF, Hou C, et al. Common variation at 6q16 within HACE1 and LIN28B influences susceptibility to neuroblastoma. Nat Genet. 2012; 44: 1126-30.

20. Capasso M, Diskin S, Cimmino F, Acierno G, Totaro F, Petrosino G, et al. Common genetic variants in NEFL influence gene expression and neuroblastoma risk. Cancer Res. 2014; 74: 6913-24.

21. Capasso M, McDaniel LD, Cimmino F, Cirino A, Formicola D, Russell MR, et al. The functional variant rs34330 of CDKN1B is associated with risk of neuroblastoma. J Cell Mol Med. 2017; 21: 3224-30.

22. Cimmino F, Avitabile M, Diskin SJ, Vaksman Z, Pignataro P, Formicola D, et al. Fine mapping of $2 q 35$ high-risk neuroblastoma locus reveals independent functional risk variants and suggests full-length BARD1 as tumor-suppressor. Int J Cancer. 2018; 143: 2828-37.

23. Brannan CI, Dees EC, Ingram RS, Tilghman SM. The product of the H19 gene may function as an RNA. Mol Cell Biol. 1990; 10: 28-36.

24. Keniry A, Oxley D, Monnier P, Kyba M, Dandolo L, Smits G, et al. The H19 lincRNA is a developmental reservoir of miR-675 that suppresses growth and Igf1r. Nat Cell Biol. 2012; 14: 659-65.

25. Kallen AN, Zhou XB, Xu J, Qiao C, Ma J, Yan L, et al. The imprinted H19 IncRNA antagonizes let-7 microRNAs. Mol Cell. 2013; 52: 101-12.

26. Verhaegh GW, Verkleij L, Vermeulen SH, den Heijer M, Witjes JA, Kiemeney LA. Polymorphisms in the H19 gene and the risk of bladder cancer. Eur Urol. 2008; 54: 1118-26.

27. Yang ML, Huang Z, Wang $\mathrm{O}$, Chen $\mathrm{HH}$, Ma SN, Wu R, et al. The association of polymorphisms in IncRNA-H19 with hepatocellular cancer risk and prognosis. Biosci Rep. 2018; 38: BSR20171652. 
28. Li L, Guo G, Zhang H, Zhou B, Bai L, Chen $\mathrm{H}$, et al. Association between $\mathrm{H} 19$ SNP rs217727 and lung cancer risk in a Chinese population: a case control study. BMC Med Genet. 2018; 19: 136

29. He J, Wang F, Zhu J, Zhang R, Yang T, Zou Y, et al. Association of potentially functional variants in the XPG gene with neuroblastoma risk in a Chinese population. J Cell Mol Med. 2016; 20: 1481-90.

30. He J, Zou Y, Wang T, Zhang R, Yang T, Zhu J, et al. Genetic Variations of GWAS-Identified Genes and Neuroblastoma Susceptibility: a Replication Study in Southern Chinese Children. Transl Oncol. 2017; 10: 936-41.

31. Zhuo ZJ, Liu W, Zhang J, Zhu J, Zhang R, Tang J, et al. Functional Polymorphisms at ERCC1/XPF Genes Confer Neuroblastoma Risk in Chinese Children. EBioMedicine. 2018; 30: 113-9.

32. Zhuo ZJ, Zhang R, Zhang J, Zhu J, Yang T, Zou Y, et al. Associations between lncRNA MEG3 polymorphisms and neuroblastoma risk in Chinese children. Aging (Albany NY). 2018; 10: 481-91.

33. Brodeur GM, Pritchard J, Berthold F, Carlsen NL, Castel V, Castelberry RP, et al. Revisions of the international criteria for neuroblastoma diagnosis, staging, and response to treatment. J Clin Oncol. 1993; 11: 1466-77.

34. He J, Zou Y, Liu X, Zhu J, Zhang J, Zhang R, et al. Association of Common Genetic Variants in Pre-microRNAs and Neuroblastoma Susceptibility: A Two-Center Study in Chinese Children. Mol Ther Nucleic Acids. 2018; 11:1-8.

35. Li Y, Zhuo ZJ, Zhou H, Liu J, Liu Z, Zhang J, et al. Additional data support the role of LINC00673 rs11655237 C>T in the development of neuroblastoma. Aging (Albany NY). 2019; 11: 2369-77.

36. Zhang J, Zhuo Z, Li W, Zhu J, He J, Su J. XRCC1 gene polymorphisms and risk of neuroblastoma in Chinese children. Aging (Albany NY). 2018; 10: 2944-53.

37. Zhang J, Yang Y, Li W, Yan L, Zhang D, He J, et al. TP53 gene rs1042522 allele $\mathrm{G}$ decreases neuroblastoma risk: a two-centre case-control study. J Cancer. 2019; 10: 467-71.

38. Cheng J, Zhuo Z, Xin Y, Zhao P, Yang W, Zhou H, et al. Relevance of XPD polymorphisms to neuroblastoma risk in Chinese children: a four-center case-control study. Aging (Albany NY). 2018; 10: 1989-2000.

39. Wang J, Zhuo Z, Chen M, Zhu J, Zhao J, Zhang J, et al. RAN/RANBP2 polymorphisms and neuroblastoma risk in Chinese children: a three-center case-control study. Aging (Albany NY). 2018; 10: 808-18.

40. Zhou H, Zhuo Z, Chen S, Zhao J, Mo Y, Zhang J, et al. Polymorphisms in MYCN gene and neuroblastoma risk in Chinese children: a 3-center case-control study. Cancer Manag Res. 2018; 10: 1807-16.

41. Lou J, Gong J, Ke J, Tian J, Zhang Y, Li J, et al. A functional polymorphism located at transcription factor binding sites, rs6695837 near LAMC1 gene, confers risk of colorectal cancer in Chinese populations. Carcinogenesis. 2017; 38: $177-83$

42. Chen X, Wang Y, Cheng K, Li J, Lou J, Ke J, et al. Genetic variants in the regulatory region of SLC10A1 are not associated with the risk of hepatitis B virus infection and clearance. Infect Genet Evol. 2016; 44: 495-500.

43. Chang J, Tian J, Yang Y, Zhong R, Li J, Zhai K, et al. A Rare Missense Variant in TCF7L2 Associates with Colorectal Cancer Risk by Interacting with a GWAS-Identified Regulatory Variant in the MYC Enhancer. Cancer Res. 2018; 78: 5164-72.

44. Chang J, Tian J, Zhu Y, Zhong R, Zhai K, Li J, et al. Exome-wide analysis identifies three low-frequency missense variants associated with pancreatic cancer risk in Chinese populations. Nat Commu. 2018; 9: 3688.

45. Chang J, Zhong R, Tian J, Li J, Zhai K, Ke J, et al. Exome-wide analyses identify low-frequency variant in CYP26B1 and additional coding variants associated with esophageal squamous cell carcinoma. Nat Genet. 2018; 50: 338-43.

46. Zhang Y, Tycko B. Monoallelic expression of the human H19 gene. Nat Genet. 1992; 1: 40-4.

47. Poirier F, Chan CT, Timmons PM, Robertson EJ, Evans MJ, Rigby PW. The murine H19 gene is activated during embryonic stem cell differentiation in vitro and at the time of implantation in the developing embryo. Development. 1991; 113: 1105-14

48. Ariel I, Lustig O, Schneider T, Pizov G, Sappir M, De-Groot N, et al. The imprinted H19 gene as a tumor marker in bladder carcinoma. Urology. 1995; 45: $335-8$

49. Ariel I, Miao HQ, Ji XR, Schneider T, Roll D, de Groot N, et al. Imprinted H19 oncofetal RNA is a candidate tumour marker for hepatocellular carcinoma. Mol Pathol. 1998; 51: 21-5.

50. Wada M, Seeger RC, Mizoguchi H, Koeffler HP. Maintenance of normal imprinting of H19 and IGF2 genes in neuroblastoma. Cancer Res. 1995; 55: 3386-8.

51. Liang WC, Fu WM, Wong CW, Wang Y, Wang WM, Hu GX, et al. The lncRNA H19 promotes epithelial to mesenchymal transition by functioning as miRNA sponges in colorectal cancer. Oncotarget. 2015; 6: 22513-25.

52. Barsyte-Lovejoy D, Lau SK, Boutros PC, Khosravi F, Jurisica I, Andrulis IL, et al. The c-Myc oncogene directly induces the H19 noncoding RNA by allele-specific binding to potentiate tumorigenesis. Cancer Res. 2006; 66: 5330-7.

53. Guo QY, Wang H, Wang Y. LncRNA H19 polymorphisms associated with the risk of OSCC in Chinese population. Eur Rev Med Pharmacol Sci. 2017; 21: 3770-4.

54. Hu C, Yang T, Pan J, Zhang J, Yang J, He J, et al. Associations between H19 polymorphisms and neuroblastoma risk in Chinese children. Biosci Rep. 2019; 39: BSR20181582.
55. Li S, Hua $\mathrm{Y}$, Jin J, Wang $\mathrm{H}$, Du M, Zhu L, et al. Association of genetic variants in lncRNA H19 with risk of colorectal cancer in a Chinese population. Oncotarget. 2016; 7: 25470-7. 